\title{
A new species of Astyanax (Ostariophysi: Characidae) from the headwaters of the arheic Río Sucuma, Catamarca, Northwestern Argentina
}

\author{
Guillermo E. Terán, Cristina I. Butí and J. Marcos Mirande
}

A new species of Astyanax is described from the arheic system of Río Sucuma, in Catamarca, Northwestern Argentina. The new species is distinguished from its congeners by a combination of characters including the presence of a broad vertical humeral spot, absence of maxillary teeth, and absence of circuli in posterior field of scales. Furthermore, this species is distinguished by the orbital diameter, head length, branched anal-fin rays, perforated lateral-line scales, transverse scales, dentary teeth with abrupt decrease in size. This species is, to date, the single known fish endemic of Río Sucuma basin.

Keywords: Arheic system, Characiformes, Cryptic species, Endemic species, Phylogeny.

Una nueva especie de Astyanax, se describe del Sistema arreico del Río Sucuma, en Catamarca, Noroeste de Argentina. Esta nueva especie se distingue de sus congéneres por una combinación de caracteres que incluyen la presencia de una gran mancha humeral, verticalmente elongada, ausencia de diente en el maxilar, ausencia de circuli en el campo posterior de las escamas, además se distingue por un ojo relativamente pequeño, longitud de la cabeza, radios ramificados en la aleta anal; escamas perforadas en la línea lateral; escamas transversas; dentario con dientes que decrecen abruptamente. Esta especie es, a la fecha, el único pez endémico para la cuenca de Río Sucuma.

Palabras clave: Characiformes, Especie críptica, Especie endémica, Filogenia, Sistema arreico.

\section{Introduction}

Astyanax Baird \& Girard includes almost 150 valid species (Eschmeyer et al., 2016). According to Eigenmann $(1917,1921)$, this genus is diagnosed by the presence of two series of teeth in the premaxilla: the first series with a variable number of teeth and the second series with usually five, crowns of premaxillary and mandibulary teeth usually ridged and denticulated, maxilla with 0-9 teeth, a complete lateral line, absence of a predorsal spine, and naked caudalfin. Most of these characters are broadly distributed among characids, evidencing that a definition of the genus is necessary (Marinho, Lima, 2009; Mirande et al., 2004, 2006a, 2007). As currently defined, Astyanax is the most diverse genus of Characidae and also the most widely distributed, inhabiting from Texas, with $A$. mexicanus (De Filippi), to the north of Argentine Patagonia, with A. pampa Casciotta, Almirón \& Azpelicueta (Casciotta et al., 2005; Pérez, 2008).

In recent years, several species similar to Astyanax eigenmanniorum (Cope, 1894) in the number of branched anal-fin rays and scales of the lateral line have been described from Argentina (A. chico Casciotta \& Almirón; A. endy Mirande Aguilera \& Azpelicueta; A. hermosus Miquelarena, Protogino \& López; A. ita Almirón, Azpelicueta \& Casciotta; A. leonidas Azpelicueta, Casciotta \& Almirón; $A$. ojiara Azpelicueta \& Garcia; A. paris Azpelicueta, Almirón \& Casciotta; A. puka Mirande, Aguilera \& Azpelicueta; A. pynandi Casciotta, Almirón, Bechara, Roux \& Ruíz Díaz; A. troya Azpelicueta, Casciotta \& Almirón; A. tumbayaensis Miquelarena \& Menni).

Catamarca province, in Northwestern Argentina, has a relatively low diversity of fishes, including only a few members of the Characidae: Astyanax lacustris (Lütken) cited as $A$. asuncionensis Géry or A. bimaculatus (Linnaeus) (see Lucena, Soares, 2016) -, A. eigenmanniorum, Bryconamericus iheringii (Boulenger), and Cheirodon interruptus (Jenyns) (Ringuelet, 1975; Azpelicueta et al., 2010; Fernández et al., 2012). The revision of collection specimens from Catamarca allowed us to discover a new species of Astyanax from an arheic river basin, which is described in this paper.

Instituto de Vertebrados, Fundación Miguel Lillo; UEL-CONICET. Miguel Lillo 251, T4000JFE - San Miguel de Tucumán, Argentina. (GET) guilloteran@gmail.com (corresponding author); (CIB) crisbuti@gmail.com; (JMM) mcmirande@gmail.com 


\section{Material and Methods}

Counts were taken as described by Fink, Weitzman (1974) and Bertaco, Lucena (2006). Counts of vertebrae, supraneurals, procurrent caudal-fin rays, gill rakers, ribs, and caudal-fin rays were taken from cleared and stained (cs) specimens prepared according to Taylor, Van Dyke (1985). Tooth counts were taken in all specimens, including cs specimens. In the descriptions, an asterisk indicates counts of the holotype and the frequency of each count is provided in parentheses.

Measurements were taken as point-to-point linear distances measured with digital caliper with a precision of $0.01 \mathrm{~mm}$, on the left side of the specimen. Measurements are expressed as percent of standard length (SL) except for subunits of the head, which are recorded as percent of head length (HL) and follow Fink, Weitzman (1974). Maxillary and postorbital lengths are measured as in Mirande et al. (2004, 2006a, 2006b, 2007). Maxillary length is measured from its articulation with the premaxilla to the maxillary tip. Postorbital distance is measured from the posterior margin of the orbit to posteriormost point of the opercular flap.

The diagnosis is presented according to the procedures described by Lucena et al. (2013) and followed by Bertaco, Vigo (2015).

Examined specimens belong to the following institutions: ANSP, Academy of Natural Sciences of Drexel University; CFA-IC, Fundación Felix de Azara, Buenos Aires; CI-FML, Colección Ictiológica Fundación Miguel Lillo, Tucumán; MACN, Museo Argentino de Ciencias Naturales, Buenos Aires; MFA-ZV- Ic, Museo Provincial de Ciencias Naturales Florentino Ameghino, Santa Fe.
The new taxon is herein added to the character matrix of Mirande (2010) and its phylogenetic relationships evaluated through a parsimony analysis. The analysis is done under extended implied weighting (Goloboff, 1993, 2014), following the procedures described by Mirande (2009) and Mirande et al. (2013). Support measures were calculated through symmetric resampling and expressed as GC values (Goloboff et al., 2003) and Bremer supports (Bremer, 1994). As absolute Bremer supports values are not much intuitive in analyses under implied weighting, they have been rescaled from 0 to 1000 using as limits the fit of the most parsimonious trees and those of the best of 100 Wagner trees (from different random addition sequences). Therefore, clades that collapse in most parsimonious trees will have a value of 0 , while those that are monophyletic in trees which are as suboptimal as the used Wagner tree, will have a value of 1000 . Those values have been calculated only for the clade of Astyanax. All searches have been done with TNT (Goloboff et al., 2008).

\section{Results}

\section{Astyanax powelli, new species}

Figs. 1-2; Tab. 1

urn:1sid:zoobank.org:act:7A84C73C-9F0C-428F-B7789F5170B54584

Holotype. CI-FML 6797, $52.3 \mathrm{~mm}$ SL, male, Argentina, Catamarca Province, El Alto, Río Sucuma, tributary of the arheic Río Las Tunas, $28^{\circ} 14^{\prime} 21^{\prime \prime} \mathrm{S} 65^{\circ} 22^{\prime} 45^{\prime \prime} \mathrm{W}$, ca. 800 meters above sea level, 22 Jun 2015, C. I. Butí.

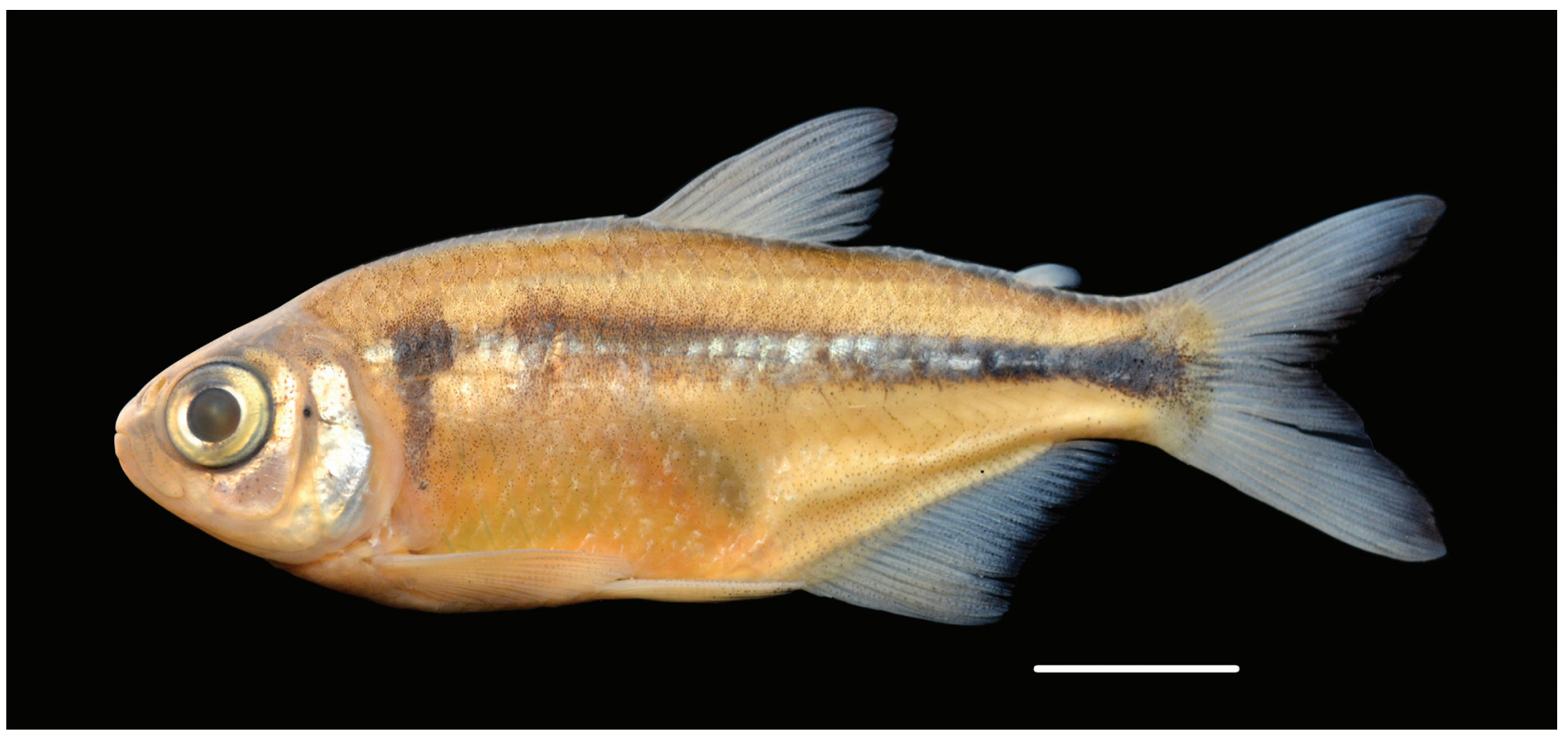

Fig. 1. Astyanax powelli, new species. CI-FML 6797, holotype, $52.3 \mathrm{~mm}$ SL, Argentina, Catamarca province, Río Sucuma. Scale bar $=10 \mathrm{~mm}$. 
Paratypes. CI-FML 6798, 40, 35.5-60.2 mm SL, (5 cs, 36.0-56.8 mm SL) collected with the holotype.

Non-types (inadequate fixing process). CI- FML 6799, $11,37.5-55.1 \mathrm{~mm}$ SL, (2, 41.6-46.6 mm SL), Argentina, Catamarca Province, Río Sucuma, tributary of the arheic Río Las Tunas, 24 Jun 2015, C. I. Butí.

Diagnosis. Astyanax powelli can be distinguished from its congeners of the Astyanax bimaculatus group (e.g. A. abramis and A. lacustris) by the vertical humeral spot (vs. horizontally oval) and the absence of circuli on posterior field of scales ( $v s$. presence). The new taxon differs from the remaining species of Astyanax by the absence of maxillary teeth (vs. presence, in a variable number). Astyanax powelli bears few denticles on the base of the first ceratobranchial gill rakers ( $v s$. broad denticles on anterior, lateral, and posterior edges of first ceratobranchial gill rakers in $A$. puka). Also, the dentary teeth decrease abruptly posterior to the fourth tooth in A. powelli (Fig. 2b) (vs. decreasing gradually in A. puka and A. cf. eigenmanniorum). Astyanax powelli bears two humeral spots (vs. one in A. rutilus (Jenyns)). In addition, males of A. powelli have bony hooks restricted to anal and pelvic-fins (vs. bony hooks in all fins in A. chico, A. tumbayaensis, and A. hermosus). Additionally, A. powelli is distinguished from A. latens Mirande, Aguilera \& Azpelicueta by the longer prepelvic distance (46.8-51.8 vs.42.6-45.8\% of SL), longer preanal distance (64.3-69.9 vs. $57.6-63.3 \%$ of SL), and shorter anal-fin base length (24.4-29.7 vs. 32.3-36.7\% of $\mathrm{SL})$. Furthermore $A$. powelli differs from $A$. hermosus and A. tumbayaensis by the relatively longer head (27.9-31.0 vs. 23.5-27.1\% of SL and 24.0-26.7\% of SL). Also, in Astyanax powelli the snout is relatively straight ( $v s$. markedly convex in A. endy and A. tumbayaensis). Astyanax tumbayaensis has a reticulated pigmentation pattern formed by finely dotted scales, especially in its posterior border, which is not evident in A. powelli. Astyanax powelli can be easily distinguished from A. lineatus (Perugia) by the absence of circuli on posterior field of scales ( $v s$. presence) and the lack of lateral stripes on the flanks (present in A. lineatus). The possession of 34-38 perforated scales of the lateral line distinguishes the new species from A. abramis and A. cordovae (Günther) (vs. 42-48 and 43-45). Astyanax tupi Azpelicueta, Mirande, Almirón \& Casciotta and A. stenohalinus Messner, possess 2-4 maxillary teeth ( $v S$. absent in A. powelli). The new species can be further distinguished from $A$. tupi and $A$. stenohalinus by the anal-fin origin located posterior to the vertical through last dorsal-fin ray insertion (vs. anal-fin origin located anterior to the vertical through last dorsal-fin ray insertion). Astyanax tupi also possesses a supraopercular spot that is absent in A. powelli. Astyanax stenohalinus is further distinguished by the possession of bony hooks on all fins of males ( $v s$. bony hooks present only in anal and pelvic-fins). Astyanax pynandi, A. ita, and A. correntinus (Holmberg) may be distinguished from the new taxon by the possession of one distally expanded maxillary tooth with
5-9 cusps (vs. tooth absent). Also, A. pynandi bears hooks on all fins of males ( $v s$. bony hooks present only in anal and pelvic fins). The relatively low number of branched analfin rays (20-26) allows the distinction of the new species from A. correntinus (29-33), A. pelegrini Eigenmann (41-47), and A. erythropterus (Holmberg) (38-45). Also, Astyanax powelli has fewer perforated scales in the lateral line (34-38 vs. 39-42, 46-52, and 47-54, respectively). Astyanax leonidas and A. troya have been described for the headwaters of streams that drain in the upper portion of the Río Parana in Argentina. Those species bear a maxillary tooth and a horizontally shaped humeral spot superimposed to a vertically elongated one ( $v s$. tooth absent and a vertically elongated spot in A. powelli). Astyanax aramburui Protogino, Miquelarena \& Lopez can be distinguished from the new taxon by the presence of a maxillary tooth ( $v s$. absent in $A$. powelli). As well, $A$. aramburui bears one humeral spot ( $v s$. two in A. powelli) and has hooks in all fins of mature males ( $v s$. hooks restricted to anal and pelvic fins).

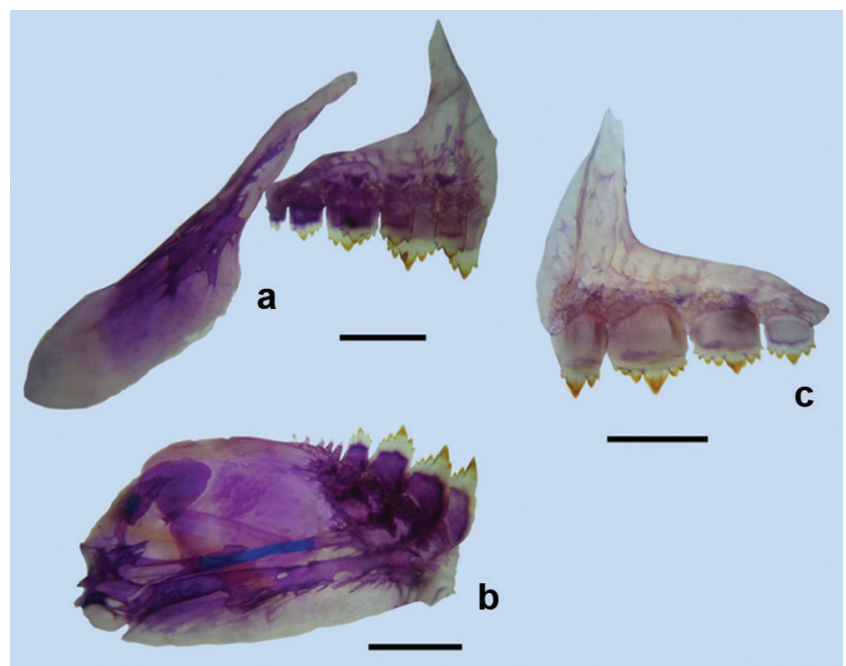

Fig. 2. Astyanax powelli, paratype CI-FML 6798. a. 57.6 $\mathrm{mm}$ SL, maxilla and premaxilla. b. Dentary, lateral view, anterior to right. c. $45.7 \mathrm{~mm} \mathrm{SL}$, premaxilla, medial view, anterior to left. Scale bars $=1 \mathrm{~mm}$.

Description. Morphometric data of holotype and 35 paratypes are presented in Tab. 1. Body slender. Maximum depth at dorsal-fin origin. Dorsal profile convex from snout to dorsal-fin origin and straight from this point to caudal peduncle; gently concave from adipose fin, along caudal peduncle, to base of caudal-fin rays. Ventral profile of body convex from lower-jaw tip to pelvic-fin origin; straight to anal-fin origin; slanted dorsally to end of anal fin, and almost straight under caudal peduncle. Dorsal-fin origin equidistant from snout tip and caudal-fin origin. Pelvic-fin origin located slightly anterior to vertical through dorsal-fin origin. Anal-fin origin just behind vertical line through base of posteriormost dorsal-fin rays. Tip of pectoral fin surpassing pelvic-fin origin and tip of pelvic fin reaching anal-fin origin in most of specimens. 
Tab. 1. Morphometric data for holotype and paratypes of Astyanax powelli, $\mathrm{n}=41$ (including holotype) from Río Sucuma basin, Catamarca, Argentina. SD = standard deviation.

\begin{tabular}{|c|c|c|c|c|}
\hline & Holotype & Range & Mean & $\mathrm{SD}$ \\
\hline Standard length $(\mathrm{mm})$ & 52.3 & $35.5-60.2$ & 46.5 & - \\
\hline \multicolumn{5}{|c|}{ Percents of standard length } \\
\hline Predorsal distance & 52.2 & $50.3-55.9$ & 53.3 & 1.2 \\
\hline Prepelvic distance & 47.7 & $46.8-51.8$ & 49.6 & 1.3 \\
\hline Prepectoral distance & 28.5 & 26.6-31.4 & 28.7 & 0.9 \\
\hline Preanal distance & 64.4 & $64.3-69.9$ & 66.9 & 1.6 \\
\hline Depth at dorsal-fin origin & 36.0 & $34.6-40.2$ & 37.4 & 1.2 \\
\hline Caudal peduncle depth & 13.3 & $12.4-14.3$ & 13.2 & 0.5 \\
\hline Caudal peduncle length & 10.4 & $9.3-12.1$ & 10.3 & 0.6 \\
\hline Anal-fin base length & 29.7 & $24.4-29.7$ & 26.9 & 1.3 \\
\hline Dorsal-fin length & 14.2 & $12.8-16.1$ & 14.3 & 0.8 \\
\hline Pelvic-fin length & 20.4 & $16.5-24.8$ & 18.9 & 1.7 \\
\hline Pectoral-fin length & 24.1 & $18.4-25.9$ & 23.2 & 1.7 \\
\hline Head length & 29.8 & $27.9-31.0$ & 29.2 & 0.8 \\
\hline Distance from pectoral-fin origin to pelvic-fin origin & 20.3 & $19.9-25.2$ & 22.5 & 1.3 \\
\hline Distance from pelvic-fin origin to anal-fin origin & 17.6 & $17.5-20.7$ & 19.2 & 0.8 \\
\hline \multicolumn{5}{|c|}{ Percents of head length } \\
\hline Snout length & 22.0 & $20.1-24.8$ & 22.6 & 1.0 \\
\hline Upper jaw length & 35.7 & $33.5-38.0$ & 35.8 & 1.2 \\
\hline Maxillary length & 23.8 & $21.5-26.2$ & 23.8 & 1.2 \\
\hline Orbital diameter & 35.6 & $31.2-36.4$ & 34.0 & 1.3 \\
\hline Interorbital width & 31.8 & $30.7-36.0$ & 32.6 & 1.4 \\
\hline Postorbital distance & 50.0 & $45.1-53.5$ & 48.9 & 1.9 \\
\hline
\end{tabular}

Mouth terminal; placed at level of inferior half of eye. Premaxilla bearing two series of teeth; outer row with 2 to 5 penta- to hexacuspidate teeth; inner row with $4(3)$ or $5\left(27^{*}\right)$ teeth; 11 specimens with 4 teeth on one side and five on other (four specimens with 4 teeth on the left side, 7 specimens with 4 teeth on the right side). Distally expanded teeth, slightly concave anteriorly; first tooth slender with 5 cusps, second to fourth teeth with 5 or 6 cusps and fifth tooth, when present, with 3 cusps. Ascending process of maxilla broad, expanded over distal part of premaxillary alveolar ramus; laminar process of maxilla short, without teeth. Dentary with 8-10 abruptly decreasing teeth, first 4 large hexa- to heptacuspidate and posterior ones tricuspidate or conical.

Eye moderately small. Third infraorbital not contacting laterosensory canal of preopercle either ventrally or posteriorly, leaving small space.

Dorsal-fin rays iii,8(2), 9(39*); first unbranched dorsal-fin ray mostly visible in cs specimens; distal margin of dorsal fin straight, with last unbranched and first branched dorsal fin rays longest. Anal-fin rays iv-v, 20(3), 21(2), 22(10), 23(16*), 24(5), 25(4), or 26(1). Males with bony hooks on distal half of last unbranched anal-fin ray and posterior branch of first 5-9 branched anal-fin rays; usually one pair of hooks per segment. Caudal-fin rays: i,16,i(1); i,17i(39*); or i,19,i(1). Pectoral-fin rays i,11(4), 12(20), 13(14*), or 14(3). Pelvic-fin rays i,7(41*); males bearing bony hooks on posterior branch of pelvic-fin rays 2 to 7 , one pair of hooks per segment. Hooks restricted to medial branches of pelvic-fin rays.
Scales cycloid, without circuli on posterior field. Lateral line complete, with $34(4), 35(10), 36(17), 37\left(4^{*}\right)$, or 38(1) perforated scales. Scales rows between dorsal-fin origin and lateral line 6(24) or 7(12*); scales rows between lateral line and pelvic-fin origin $5\left(36^{*}\right)$. Scales rows around caudal peduncle 14(15), 15(10), 16(8*), or 17(3). Predorsal scales $10-14^{*}$, forming relative regular row. One row of scales forming a sheath, covering base of unbranched and first 8-14 branched anal-fin rays. Few scales covering base of caudalfin lobes.

In cs specimens (5), first gill arch with 20-22 rakers: 7-8 on epibranchial, 1 on cartilage, 9-11 on ceratobranchial, and 2-3 on hypobranchial; posterior margin of first epibranchial with a second row of 4-6 gill rakers. Thirty-four total vertebrae (17 precaudal and 17 caudal). Five supraneurals, 11 pairs of ribs. Caudal fin with 8 or 9 dorsal and 9 or 10 ventral procurrent rays.

Color in alcohol. Uniformly yellowish, darker dorsally. Two humeral spots. Anterior one conspicuous, black, vertically elongated, upper portion wider and darker; extended from third row over the lateral line to second row under lateral line. Second spot large, diffuse, and dark, continuous with dark lateral stripe. Lateral stripe silvery in specimens with less time in formaldehyde. Lateral stripe limited posteriorly by a black, triangular, caudal spot extended, although not conspicuously, to tip of middle caudal-fin rays. Dorsal, anal, pelvic, and adipose fins hyaline (Fig. 1). 
Sexual dimorphism. Males bear hooks in the first 5 to 9 branched anal-fin rays and in all branched pelvic-fin rays excepting the last one. Fusion of the anteriormost gill filaments, as in other species of Astyanax (Terán et al., 2015) was found in mature males. Protogino et al. (2006) mentioned the presence of breeding tubercles in head and scales in mature males of $A$. aramburui. These tubercles were not found in this species, but they were found in some specimens of $A$. eremus Ingenito \& Duboc (Ingenito, Duboc, 2014), A. gymnodontus (Eigenmann) (CI-FML 7138), A. ojiara (CI-FML 6779), A. parahybae (Eigenmann) (CI-FML 7174), and A. troya (CI-FML 7175) and may have a wider distribution in the genus. These tubercles are probably related with the sexual maturity and their presence in A. powelli cannot be discarded.

Geographical distribution. Headwaters of Río Sucuma upstream of Dos Afluentes dam, in Department El Alto, Province of Catamarca (Figs. 3, 4).

Ecological notes. The new species inhabits mountain environments with high flow velocity and gravel substrate with clear waters. The river has abundant water vegetation such as Myriophyllum aquaticum and undetermined Poaceae and floating vegetation (Hydrocotyle ranunculoides and Azolla filiculoides). As well, the presence of green algae is common in these environments.

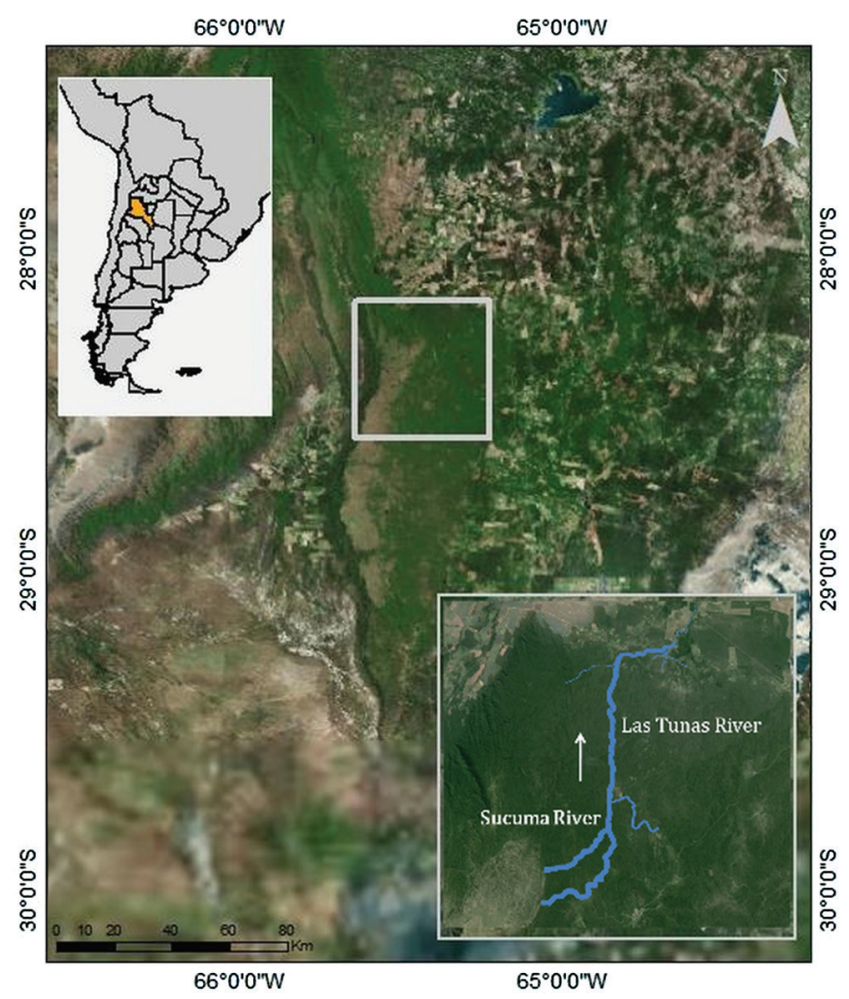

Fig. 4. Map of northwestern Argentina, showing the type locality of Astyanax powelli, Río Sucuma, Catamarca. Arrow indicates sense of flow.

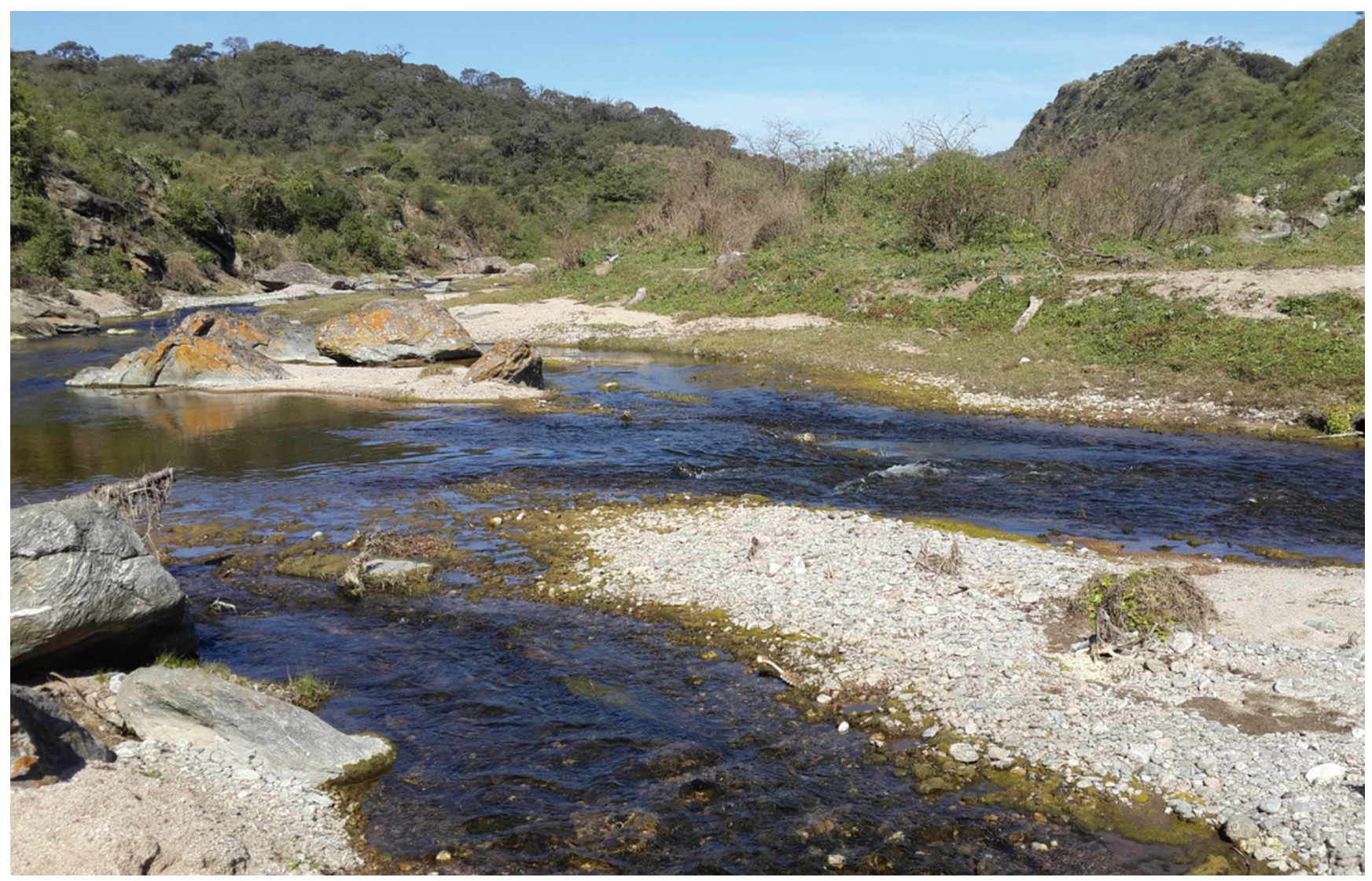

Fig. 3. Headwaters of Río Sucuma, type locality of Astyanax powelli, Catamarca province, Argentina. 
Astyanax powelli is confined to the arheic system of the Río Sucuma. This area belongs to the ecorregion of Mar Chiquita - Salinas Grandes, according to Hales, Petry (2015), which comprises several arheic and endorheic basins. Even though the upper portion of the river does not present mayor threats, the lower portion of this river system is under strong anthropic pressure, with the whole river outrageously channeled to satisfy demands from agriculture and population.

Etymology. The species name, powelli is in honor and memory to the late Dr. Jaime Eduardo Powell; prominent paleontologist, dear friend, and colleague. A noun in genitive case.

Conservation status. Even though the known geographic distribution of $A$. powelli is restricted and that the lower portion of the basin is entirely channeled for agriculture, no threats to the species were detected in the upper portion of the basin. Therefore, Astyanax powelli can be classified as Least Concern (LC), according to the International Union for Conservation of Nature (IUCN) categories and criteria (IUCN, 2016).

Remarks. All the analyses performed, see coding in Appendix 1 (S1 - Available only as online supplementary file accessed with the online version of the article at http://www.scielo.br/ni), with values of $\mathrm{K}$ ranging from 5.26 to 47.35 (see Mirande, 2009 for details), agree in the monophyly of a clade composed of all the analyzed species of Astyanax and including also Astyanacinus Eigenmann, Markiana Eigenmann, Psellogrammus Eigenmann, and Hyphessobrycon anisitsi (Eigenmann), in a result similar to that obtained by Mirande et al. (2011). Relationships within this clade are stable in the most parsimonious trees obtained in the 11 lower (stronger) values of $\mathrm{K}$, ranging from 5.26 to 13.53 (Fig. 5 ), although most clades are weakly supported, as in previously published phylogenetic hypotheses (Mirande, 2009, 2010). In these analyses, Astyanax powelli is the sister group of all the remaining species of the clade, excepting $A$. latens and $A$. paris. In higher (milder) values of $\mathrm{K}, A$. powelli is obtained as the sister group of a clade composed of Astyanacinus moorii (Boulenger), Astyanax abramis, A. lacustris, A. lineatus, A. pelegrini Eigenmann, Markiana nigripinnis (Perugia), and Psellogrammus kennedyi (Eigenmann), in a rather odd result that is also weakly supported.

The aim of this phylogenetic analysis is not to resolve the relationships of Astyanax, which is far beyond the scope of this paper, but to obtain some idea about the phylogenetic relationships of $A$. powelli and the cryptic species with which the new taxon is sympatric ( $A$. cf. eigenmanniorum and $A$. puka). The new taxon was not obtained as sister group of those species in any of the analyses performed herein.

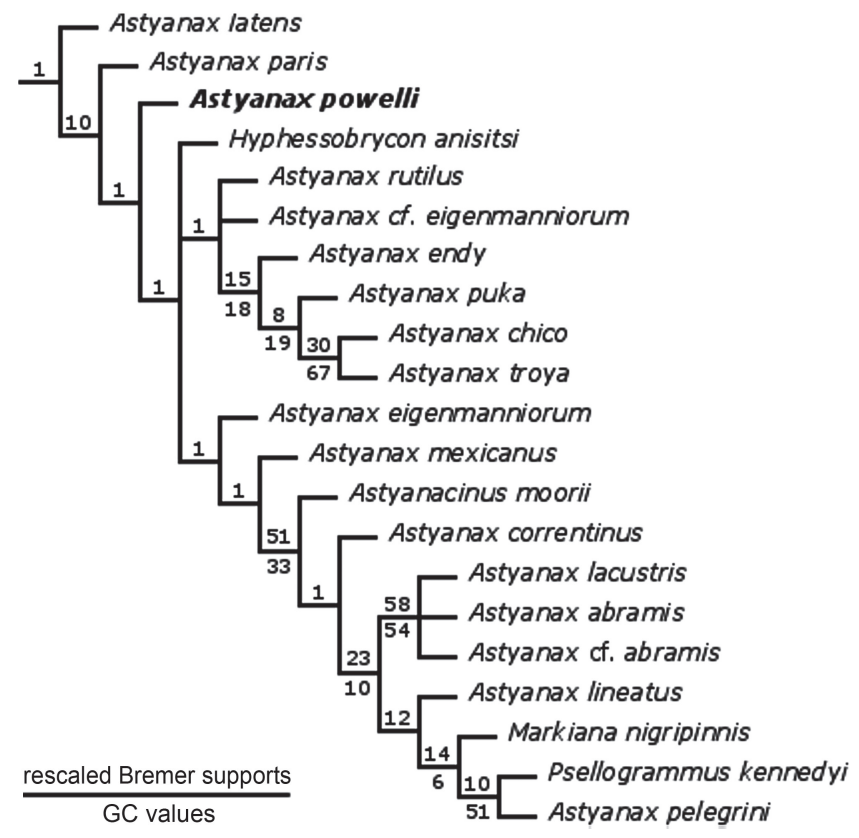

Fig. 5. Detail of the Astyanax clade in the most parsimonious tree obtained from values of $\mathrm{K}$ between 5.26 and 13.53. Numbers above branches are rescaled Bremer supports (see material and methods section) and numbers below branches are $\mathrm{GC}$ values in clades having positive values.

\section{Discussion}

The new species shares most of the meristic data with Astyanax eigenmanniorum. That species was described from laguna dos Patos system, Rio Grande do Sul, Brazil, but it has a broad distribution and may actually represent a complex of species that should be carefully revised, as noted by Malabarba (1989) and Vari, Castro (2007).

Species of Astyanax with similar counts than $A$. eigenmanniorum have been recorded in several basins of Argentina. Astyanax powelli can be easily distinguished from all those species by the absence of maxillary teeth. Also, the holotype of A. eigenmanniorum has a shorter snout, of 16.2\% (Vari, Castro, 2007) vs. 20.1-24.8 \% HL in A. powelli.

The species of Astyanax known to lack maxillary teeth belong to the A. bimaculatus-group (as A. abramis and A. lacustris), which share the presence of an ovate humeral spot and circuli on posterior field of scales (e.g. Mirande, 2010). Astyanax powelli clearly does not belong to the Astyanax bimaculatus species complex (Garutti, Britski, 2000), having a vertical humeral spot and lacking circuli on posterior field of scales. The new taxon, also, was not found as closely-related to $A$. abramis and $A$. lacustris in the phylogenetic analysis herein performed. The lack of a maxillary tooth in $A$. powelli is an autapomorphy that readily distinguishes it from closely related species.

The following Astyanax species occur in the northwestern Argentina: Río Sali basin: A. abramis, A. cf. eigenmanniorum, A. lacustris, A. rutilus, and A. puka 
(Butí, Cancino, 1999, 2005; Mirande et al., 2007); Río Juramento basin: $A$. abramis, $A$. cf. eigenmanniorum, $A$. lacustris, A. lineatus, and A. puka (Terán et al., 2014). Río Bermejo basin: A. abramis, A. endy, A. chico, A. lacustris, A. latens, A. lineatus, and A. tumbayaensis (Mirande et al., 2006a). The following species have been recorded in the lower Río Paraná in Argentina: A. abramis, A. aramburui, A. correntinus, $A$. cf. eigenmanniorum, A. erythropterus, A. lacustris, A. leonidas -Urugua-í-, A. lineatus, $A$. pelegrini, A. pynandi, A. rutilus, A. stenohalinus, A. tupi -Cuña-Pirú-, A. troya -Cuña-Pirú- (Almirón et al., 2015; Azpelicueta et al., 2002; Liotta, 2005; Lucena, Soares, 2016; Mirande et al., 2006b; Protogino et al., 2006). The new species was distinguished from all those species in the Diagnosis section.

Astyanax powelli can be easily distinguished from the remaining species of Astyanax that occur in the lower Río Uruguay basin. Astyanax saguazu Casciotta, Almirón \& Azpelicueta, and A. paris possess 2-4 maxillary teeth (vs. absent in A. powelli). The new species can be further distinguished from $A$. saguazu by the anal-fin origin located posterior to the vertical through last dorsal-fin ray insertion ( $v s$. anal-fin origin located anterior to a vertical through last dorsal-fin ray insertion). In addition, $A$. paris possesses a supraopercular spot that is absent in $A$. powelli. The large eye of $A$. saguazu (41.1-45.5\% of HL) allows its distinction from $A$. powelli (31.2-36.4\% of HL). Astyanax ojiara and $A$. dissensus Lucena \& Thofehrn may be distinguished from the new taxon by the possession of one distally expanded maxillary tooth with 7-9 cusps ( $v s$. tooth absent). Also, A. ojiara possesses hooks on all fins of males ( $v s$. bony hooks present in anal and pelvic-fins).

Astyanax xiru Lucena, Castro \& Bertaco is distributed in the upper Río Uruguay basin (Casciotta et al., 2016; Lucena et al., 2013). This species can be easily distinguished from $A$. powelli by the shape of the first humeral spot: upper portion horizontally elongate and lower portion vertically narrow (vs. vertically elongated).

Astyanax pampa is one of the species of Characiformes with the southernmost distribution in South America, inhabiting Las Mostazas stream, the lower Río Colorado basin (southern Buenos Aires Province), and Río Negro drainage (Río Negro Province) (Casciotta et al., 2005; Pérez, 2008). This species is mainly distinguished from $A$. powelli by the presence of one maxillary teeth ( $v s$. absent) and a lower number of branched anal fin rays (17-20 vs. 20-26 in A. powelli); some specimens of A. pampa have 5 scales rows between the lateral line and the dorsal-fin origin, while this condition was not found in A. powelli, and all the examined specimens have 6 or 7 rows instead.

The Río Sucuma flows northward to Río Las Tunas, forming together an arheic basin. The closest river drainage is the Río Salí basin. The type locality of Astyanax puka is in the Río Salí basin and the presence of this species living sympatrically with $A$. powelli at the Río Sucuma may evidence some historical and/or occasional connection between these two basins, as previously noted by Azpelicueta et al. (2010). Species with restricted ranges of distribution, especially those inhabiting arheic systems (e.g. Astyanax powelli in the Río Sucuma-Las Tunas basin), may be considered as more susceptible to environmental impacts. Therefore, such basins and their faunas should receive special attention in the research efforts and planning of conservation strategies.

Comparative material examined. Astyanax abramis. Argentina. Corrientes. CI-FML 5422, 26, 63.7-90.3 mm SL. CI-FML 5173, 10, 60.1-78.9 mm SL. CI-FML 6770, 8, 98.3-107.6 mm SL. Astyanax aramburui. Argentina. Entre Ríos. CFA-IC 11712, 61.1 mm SL, holotype. Astyanax chico. Argentina. Salta. CI-FML 3913, 6, 65.2-80.41 mm SL. Astyanax correntinus. Argentina. Corrientes. CI-FML 3826, 10, 68.7-75.6 mm SL. Astyanax dissensus. Argentina. Corrientes. CI-FML 6183, 20, 54.3-88.6 mm SL. Astyanax eigenmanniorum. Brazil. Rio Grande do Sul. ANSP 21599-601, 3, 35.4-47.3 mm SL, paratypes. CI-FML 5468, 20, 43.3-56.9 mm SL. Astyanax cf. eigenmanniorum. Argentina. Catamarca. CI-FML 7178, 6, 43.2-65.2 mm SL. Tucumán. CI-FML 3037, 40, 45.6-60.6 mm SL. Astyanax endy. Argentina. Salta. CI-FML 3834, 55.8 mm SL, holotype. CI-FML 3835, 14, 48.6-56.3 mm SL, paratypes. Astyanax erythropterus. Argentina. Santa Fe. MFA-ZV- Ic 2872, 12 of 22, 35.4-69.2 mm SL, MFA-ZV- Ic 2874, 9, 47.0-71.2 mm SL. Astyanax hermosus. Argentina. Córdoba. CFA-IC 1169078.5 mm SL, holotype. Astyanax ita. Argentina. Misiones. CI-FML 7121, 2, 58.0-59.7 mm SL. Astyanax lacustris. Argentina. CI-FML 3416, 6, 42.1$50.1 \mathrm{~mm}$ SL. CI-FML 5802, 15, 51.1-64.8 mm SL. Paraguay. Bahia Negra. CI-FML 3910, 50, 44.9-62.6 mm SL. Astyanax latens. Argentina. Salta. CI-FML 3400, $44.3 \mathrm{~mm}$ SL, holotype. CI-FML 3401, 5, 46.8-52.4 mm SL, paratypes. CI-FML 3402, 10, 42.8-47.8 mm SL, paratypes. Astyanax leonidas. Argentina. Misiones. CI-FML 5470, 71, 52.1-73.9. Astyanax lineatus. Argentina. Salta. CI- FML 3884, 54, 71.1-83.5. Astyanax mexicanus. United States of America. Texas. ANSP 162587, 4, 39.4-48.5 mm SL. Argentina. Misiones. CI-FML 6779, 15, 42.4$65.03 \mathrm{~mm}$ SL. Astyanax paris. Argentina. Misiones. CI-FML 3919, 16, 48.8-66.3 mm SL. Astyanax pelegrini. Paraguay. Bahia Negra. CI-FML 3847, 35, 50.4-73.3 mm SL. Astyanax puka. Argentina. Tucumán. CI-FML 3844, $50.3 \mathrm{~mm}$ SL, holotype. CI-FML 3849, 19, 44.8-59.5 mm SL, paratypes. CI-FML 3850, 3, 42.7-50.0 mm SL. CI-FML 7176, 1, $54.35 \mathrm{~mm}$ SL. Astyanax pynandi. Argentina. Buenos Aires. CI- FML 7105, 2, 46.8-54.0 $\mathrm{mm}$ SL. Astyanax rutilus. Argentina. Rosario. CI-FML 7013, 16, 35.1-69.9 mm SL. Tucumán. CI-FML 7177, 4, 46.2-63.6 mm SL, Simoca. Astyanax saguazu. Uruguay. Artigas. CI-FML 5807, 15, 46.4-73.6 mm SL. Astyanax stenohalinus. Uruguay. Durazno. CI-FML 5811, 2, 59.1-70.9 mm SL. Argentina. Jujuy. CFA-IC 11702, $68.8 \mathrm{~mm}$, holotype. CI-FML 3845, 15, 57.1-75.8 mm SL. CI-FML 5123, 7, 42.7-46.1 mm SL. Astyanax tupi. Argentina. Misiones. MACN-ICT 8646, $70.1 \mathrm{~mm}$. SL, holotype. Astyanax troya. Argentina. Misiones. CI-FML 3920, 16, 56.3-91.0 mm SL, CI-FML 5466, 16 (2cs) 52.7-89.4 mm SL, CI-FML 7140, 4, 73.0-76.8 mm SL. 


\section{Acknowledgments}

The authors thank Carlos Lucena (MCP), Luiz Malabarba (UFRGS), Sonia Fisch-Muller (MHNG), Flávio Lima (ZUEC), Mark Sabaj-Pérez and John Lundberg (ANSP), Carlos Virasoro and Andrés Pautasso (MFA), Ignacio Garcia and Florencia Brancolini (Instituto de Limnología "Dr. Raúl A. Ringuelet), for loan or exchange of specimens. Pablo Pereyra and Patricia Asesor (FML) for helping with the graphics. Felipe Alonso (MACN), Gastón Aguilera (FML), Luis Lobo, Sergio Bogan (CFA) and Mercedes Azpelicueta (CONICET), for permanent support. This work was supported by Colegio de Biólogos Tucumán. This manuscript was partly built under a Linux platform. We thank ArchLinux, Manjaro, GIMP and LibreOffice communities. CIB is grateful with Horacio Catalán S.R.L for support in the field trips. We are also thankful to the Fundación Miguel Lillo and CONICET. (PIP-11420110100301 to JMM) and FONCyT (PICT2008-1201 and PICT-2011-0992 to JMM). This manuscript greatly benefited from comments and suggestions of Paulo Lucinda (UNT) and two reviewers.

\section{References}

Almirón AE, Casciotta JR, Ciotek L, Giorgis P. Guía de los peces del Parque Nacional Pre-Delta. 2nd ed. Ciudad Autónoma de Buenos Aires: Administración de Parques Nacionales; 2015.

Azpelicueta MM, Casciotta JR, Almirón AE. Two new species of the genus Astyanax (Characiformes, Characidae) from the Paraná river basin in Argentina. Rev Suisse Zool. 2002; 109(2):243-59.

Azpelicueta MM, Méndez CMD, Cancino F. New records of fishes from Catamarca, Argentina. Ichthyological Contributions of PecesCriollos. 2010; 16:1-3.

Bertaco VA, Lucena CAS. Two new species of Astyanax (Ostariophysi: Characiformes: Characidae) from eastern Brazil with a synopsis of the Astyanax scabripinnis species complex. Neotrop Ichthyol. 2006; 4(1):53-60.

Bertaco VA, Vigo AC. A new species of Astyanax Baird \& Girard (Ostariophysi: Characidae) from the rio Taquari-Antas basin, southern Brazil. Neotrop Ichthyol. 2015; 13(2):265-72.

Bremer K. Branch support and tree stability. Cladistics. 1994; 10(3):295-304.

Butí C, Cancino F. Ictiofauna del embalse río Hondo (TucumánSantiago del Estero), cuenca del río Salí-Dulce, Argentina. Acta Zool Lilloana. 1999; 45(1):67-77.

Butí C, Cancino F. Ictiofauna de la cuenca endorreica del río SalíDulce, Argentina. Acta Zool Lilloana. 2005; 49(1-2):9-34.

Casciotta JR, Almirón AE, Azpelicueta MM. Astyanax pampa (Characiformes, Characidae), a new species from the southernmost boundary of the Brazilian subregion, Argentina. Rev Suisse Zool. 2005; 112(2):401-08.

Casciotta JR, Almirón AE, Říčanová Š, Dragová K, Piálek L, Říčan O. First record of Astyanax xiru Lucena, Castro \& Bertaco, 2013 (Characiformes: Characidae) from the río Uruguay basin of Argentina. Ichthyol Contrib PecesCriollos. 2016; 42:1-4.
Eigenmann $\mathrm{CH}$. The american Characidae. Mem Mus Comp Zool. 1917; 43(1):1-102.

Eigenmann $\mathrm{CH}$. The american Characidae. Mem Mus Comp Zool. 1921; 43(3):209-310.

Eschmeyer WN, Fricke R, van der Laan R, editors. Catalog of fishes: genera, species, references [Internet]. San Francisco: California Academy of Science; 2016 [updated 2016 Sep 29; cited 2016 Oct 15]. Available from: http:// researcharchive.calacademy.org/research/ichthyology/ catalog/fishcatmain.asp

Fernández L, Fuchs DV, Nadalin DO, López HL. Lista de los peces de la provincia de Catamarca. Argentina: ProBiota, FCNyM, UNLP; 2012. (Serie Técnica y Didáctica; No. 17).

Fink WL, Weitzman SH. The so-called cheirodontin fishes of Central America with descriptions of two new species (Pisces: Characidae). Washington (DC): Smithsonian Institution Press; 1974. (Smithsonian Contributions to Zoology; No. 172).

Garutti V, Britski HA. Descrição de uma espécie nova de Astyanax (Teleostei: Characidae) da bacia do alto rio Paraná e considerações sobre as demais espécies do gênero na bacia. Com Mus Ciênc Tecnol PUCRS. 2000; 13(1):65-88.

Goloboff PA. Estimating character weights during tree search. Cladistics. 1993; 9(1):83-91.

Goloboff PA. Extended implied weighting. Cladistics. 2014; 30(3):260-72.

Goloboff PA, Farris JS, Källersjö M, Oxelman B, Ramírez MJ, Szumik CA. Improvements to resampling measures of group support. Cladistics. 2003; 19(4):324-32.

Goloboff, PA, Farris JS, Nixon KC. TNT, a free program for phylogenetic analysis. Cladistics. 2008; 24(5):774-86.

Hales J, Petri P. 339: Mar Chiquita - salinas grandes. In: Freshwater Ecoregions of the World. [Image maps on the Internet]. Zuerich, Switzerland: WWW/TNC; c2013. [cited 2017 May 20]. Available from: http://www.feow.org/ ecoregions/details/339. Last updated: October 2, 2015.

Ingenito LF, Duboc LF. A new species of Astyanax (Ostariophysi: Characiformes: Characidae) from the upper rio Iguaçu basin, southern Brazil. Neotrop Ichthyol. 2014; 12(2):281-90.

International Union for Conservation of Nature (IUCN). Standards and Petitions Subcommittee. Guidelines for using the IUCN Red List Categories and Criteria. Version 12 [Internet]. 2016 [updated 2016 Feb]. Available from: http:// cmsdocs.s3.amazonaws.com/RedListGuidelines.pdf

Liotta J. Distribución geográfica de peces de aguas continentales de la República Argentina. Argentina: ProBiota, FCNyM, UNLP; 2005. (Serie Documentos; No. 3).

Lucena CAS, Castro JB, Bertaco VA. Three new species of Astyanax from drainages of southern Brazil (Characiformes: Characidae). Neotrop Ichthyol. 2013; 11(3):537-52.

Lucena CAS, Soares HG. Review of species of the Astyanax bimaculatus "caudal peduncle spot" subgroup sensu Garutti \& Langeani (Characiformes, Characidae) from the rio La Plata and rio São Francisco drainages and coastal systems of southern Brazil and Uruguay. Zootaxa. 2016; 4072(1):101-25. 
Malabarba LR. Histórico sistemático e lista comentada das espécies de peixes de água doce do sistema da Laguna dos Patos, Rio Grande do Sul, Brasil. Com Mus Ciênc Tecnol PUCRS. 1989; 2(8):107-79.

Marinho MMF, Lima FCT. Astyanax ajuricaba: a new species from the Amazon basin in Brazil (Characiformes: Characidae). Neotrop Ichthyol. 2009; 7(2):169-74.

Mirande JM. Weighted parsimony phylogeny of the family Characidae (Teleostei: Characiformes). Cladistics. 2009; 25(6):574-613.

Mirande JM. Phylogeny of the family Characidae (Teleostei: Characiformes): from characters to taxonomy. Neotrop Ichthyol. 2010; 8(3):385-568.

Mirande JM, Aguilera G, Azpelicueta MM. A new species of Astyanax (Characiformes, Characidae) from the upper río Bermejo basin, Salta, Argentina. Rev Suisse Zool. 2004; 111(1):213-24.

Mirande JM, Aguilera G, Azpelicueta MM. Astyanax endy (Characiformes: Characidae), a new fish species from the upper río Bermejo basin, northwestern Argentina. Zootaxa. 2006a; 1286(1):57-68.

Mirande JM, Aguilera G, Azpelicueta MM. A new species of Astyanax (Characiformes: Characidae) from the endorheic río Salí basin, Tucumán, northwestern Argentina. Zootaxa. 2007; 1646(1):31-9.

Mirande JM, Aguilera G, Azpelicueta MM. A threatened new species of Oligosarcus and its phylogenetic relationships, with comments on Astyanacinus (Teleostei: Characidae). Zootaxa. 2011; 2994(1):1-20.

Mirande JM, Azpelicueta MM, Aguilera G. Redescription of Astyanax correntinus (Holmberg, 1891) (Teleostei: Characiformes: Characidae), more than one hundred years from original description. Zool Abh. 2006b; 55:9-15.
Mirande JM, Jerep FC, Vanegas-Ríos JA. Phylogenetic relationships of the enigmatic Carlastyanax aurocaudatus (Eigenmann) with remarks on the phylogeny of the Stevardiinae (Teleostei: Characidae). Neotrop Ichthyol. 2013; 11(4):747-66.

Pérez CHF. Fish, southernmost record of Astyanax pampa (Ostariophysi, Characiformes, Characidae). Check List. 2008; 4(4):424-26.

Protogino LC, Miquelarena AM, López HL. A new species of Astyanax (Teleostei, Characiformes, Characidae), with breeding tubercles, from the Paraná and Uruguay river basins. Zootaxa. 2006; 1297(1):1-16.

Ringuelet RA. Zoogeografía y ecología de los peces de aguas continentales de la Argentina y consideraciones sobre las áreas ictiológicas de América del Sur. Ecosur. 1975; 2(3):1-122.

Taylor WR, Van Dyke GC. Revised procedures for staining and clearing small fishes and other vertebrates for bone and cartilage study. Cybium. 1985; 9(2):107-19.

Terán GE, Mangione S, Mirande JM. Gill-derived glands in species of Astyanax (Teleostei: Characidae). Acta Zool (Stockholm). 2015; 96(3):335-42.

Terán GE, Aguilera G, Mirande JM. First record of Astyanax puka Mirande, Aguilera \& Azpelicueta, 2007 (Teleostei: Characidae) in Juramento river basin, Salta, Argentina. Check List. 2014; 10(5):1231-33.

Vari RP, Castro RMC. New species of Astyanax (Ostraiophysi: Characiformes: Characidae) from the upper Rio Paraná system, Brazil. Copeia. 2007; 2007(1):150-62.

Submitted May 29, 2016 Accepted April 21, 2017 by Paulo Lucinda 
